\title{
Microbial Enhanced Heavy Oil Recovery by the Aid of Inhabitant Spore-Forming Bacteria: An Insight Review
}

\author{
Biji Shibulal, ${ }^{1}$ Saif N. Al-Bahry, ${ }^{1}$ Yahya M. Al-Wahaibi, ${ }^{2}$ \\ Abdulkader E. Elshafie, ${ }^{1}$ Ali S. Al-Bemani, ${ }^{2}$ and Sanket J. Joshi ${ }^{1,3}$ \\ ${ }^{1}$ Department of Biology, College of Science, Sultan Qaboos University, 123 Muscat, Oman \\ ${ }^{2}$ Petroleum and Chemical Engineering Department, College of Engineering, Sultan Qaboos University, 123 Muscat, Oman \\ ${ }^{3}$ Central Analytical and Applied Research Unit, College of Science, Sultan Qaboos University, 123 Muscat, Oman
}

Correspondence should be addressed to Saif N. Al-Bahry; snbahry@squ.edu.om

Received 28 August 2013; Accepted 20 October 2013; Published 16 January 2014

Academic Editors: Z. He, A. Piacentino, and H. Tsutsumi

Copyright (C) 2014 Biji Shibulal et al. This is an open access article distributed under the Creative Commons Attribution License, which permits unrestricted use, distribution, and reproduction in any medium, provided the original work is properly cited.

\begin{abstract}
Crude oil is the major source of energy worldwide being exploited as a source of economy, including Oman. As the price of crude oil increases and crude oil reserves collapse, exploitation of oil resources in mature reservoirs is essential for meeting future energy demands. As conventional recovery methods currently used have become less efficient for the needs, there is a continuous demand of developing a new technology which helps in the upgradation of heavy crude oil. Microbial enhanced oil recovery (MEOR) is an important tertiary oil recovery method which is cost-effective and eco-friendly technology to drive the residual oil trapped in the reservoirs. The potential of microorganisms to degrade heavy crude oil to reduce viscosity is considered to be very effective in MEOR. Earlier studies of MEOR (1950s) were based on three broad areas: injection, dispersion, and propagation of microorganisms in petroleum reservoirs; selective degradation of oil components to improve flow characteristics; and production of metabolites by microorganisms and their effects. Since thermophilic spore-forming bacteria can thrive in very extreme conditions in oil reservoirs, they are the most suitable organisms for the purpose. This paper contains the review of work done with thermophilic spore-forming bacteria by different researchers.
\end{abstract}

\section{Background}

Oil productions have been experiencing decline in many parts of the world due to the oil field maturity, and example of such includes the major oil fields in the North Sea [1]. Another major factor which causes downgrade is the increasing energy demands due to global population growth and the difficulty in discovering new oil fields as an alternative to the exploited oil fields. Therefore, there is an urge to find out alternative technologies to increase oil recovery from existing oil fields around the world. It is a fact that fossil fuels will still remain the key source of energy, regardless of the gross investments in other energy sources such as biofuels, solar energy, and wind energy. Current global energy production from fossil fuels represents about $80-90 \%$ with oil and gas typifying about $60 \%$ [2]. Cossé [3] stated that during the process of oil production, between 30 and $40 \%$ of oil can be contributed by primary oil recovery, while additional 15$25 \%$ can be recovered by secondary methods such as water injection leaving behind about $35-55 \%$ of oil as residual oil in the reservoirs. The focus of many enhanced oil recovery technologies is this residual oil, and it amounts to about 24 trillion barrels [4] or about $67 \%$ of the total oil reserves [5]. For many oil companies, residual oil recovery is at present unavoidable, and so there is a perpetual hunt for a cheap and efficient technology which will raise the global oil production as well as the productive life of many oil fields. The recovery of this residual oil is accomplished by enhanced oil recovery (EOR) or tertiary recovery methods which are used in oil industry to increase the production of crude oil. Most common tertiary recovery methods include chemical flooding, miscible $\mathrm{CO}_{2}$ injection, and thermally enhanced oil recovery method which uses heat as a main source for the additional oil recovery [6]. Large quantities of 
residual oil in the depleted oil reservoirs could be regained by these EOR methods as the current primary and secondary extraction methods leave about two-thirds of the original oil in the reservoir. One of the potential EOR methods is microbial enhanced oil recovery (MEOR), which employs microorganisms to pull out the remaining oil from the reservoirs. Up to $50 \%$ of the residual oil can be extracted by this exceptionally low operating cost technology $[7,8]$. The field trials of MEOR method project a chance to reverse the declining trend of oil production or at least to maintain a curve with a positive slope. This is achieved by the alteration of chemical and physical properties of reservoir rocks and crude oil by the microbial growth and metabolites produced [9]. MEOR can overcome the main hindrances of efficient oil recovery such as low reservoir permeability, high viscosity of the crude oil, and high oil-water interfacial tensions, which in turn result in high capillary forces retaining the oil within the reservoir rock [10].

\section{The Reasons for Oil to Get Left Behind}

The fundamental cause for leaving oil behind is economics. In general, the process of recovering oil from any conventional reservoir requires (a) a pathway which connects oil in the pore space of a reservoir to the surface and (b) sufficient energy in the reservoir to drive the oil to the surface. Lack of these requirements in the environment results in oil getting left behind. In this case, it is not economical to implement incremental development activities. In addition, all of the theoretically displaceable oil cannot be recovered, even if there is a pathway and adequate reservoir energy, due to the physics of fluid displacement in porous media [11].

\section{Enhanced Oil Recovery}

The residual crude oil in reservoirs is up to $67 \%$ of the total petroleum reserves in the world, which in turn represents the relative inefficiency of the primary and secondary production techniques. Extraction of this trapped oil can be achieved by injecting chemicals (polymers or surfactants), gases (carbon dioxide, hydrocarbons, or nitrogen), or steam into the reservoir. The chemicals used for EOR must be compatible with the physical and chemical environments of oil reservoirs. The varying permeability of petroleum reservoirs is also a major concern in EOR processes. When water is injected to displace the oil, it preferentially flows through areas of highest permeability and bypasses much of the oil [12]. Thus, the conventional EOR methods to recover the entrapped crude oil seem not to be very efficient.

\section{Microbial Enhanced Oil Recovery (MEOR)}

MEOR is a tertiary oil recovery technique. Recovering oil usually requires three stages. At the primary recovery only $12 \%$ to $15 \%$ of the oil in the well is recovered without the need to introduce other substances into the well. The oil well is then flooded with water or other substances to drive out an additional oil (15\% to $20 \%$ ) from the well which is known as the secondary recovery. Tertiary recovery is the last phase which is accomplished through several different methods, including MEOR, for the additional extraction of trapped oil from the well. In principle, the process of MEOR results in some beneficial effects such as formation of stable oil-water emulsions reduced interfacial tension and clogging the high permeable zones. In in situ MEOR method, bacteria inoculated with water in to the well will progress into highpermeability zones at first. Then at a later stage they will grow and occlude those zones due to their size and the negative charge on their cell surface. This scenario helps to increase the sweep efficiency, and thus a more efficient oil recovery can be achieved $[11,13]$.

Microorganisms can synthesize useful products by fermenting low-cost substrates or raw materials. Therefore, MEOR can substitute chemical enhanced oil recovery (CEOR), which is a very pricey technology. In MEOR, the chosen microbial strains are used to synthesize compounds analogous to those used in CEOR processes which are very expensive, to increase the recovery of oil from depleted and marginal reservoirs. Furthermore, microbial products are biodegradable and have low toxicity [7, 14, 15]. Microbial technologies are becoming approved universally as lucrative and eco-friendly approaches to improve oil production [16, 17].

\section{MEOR Outcomes}

MEOR is based on two absolute justifications. Oil advancement through porous media is expedited by modifying the interfacial properties of the oil-water minerals. In such a system, microbial activity alters fluidity (viscosity reduction, miscible flooding); displacement efficiency (decrease of interfacial tension, increase of permeability); sweep efficiency (mobility control, selective plugging); and driving force (reservoir pressure).

The second principle is known as upgrading. In this case, the degradation of heavy oils into lighter ones occurs by microbial activity. Instead, it can also aid in the removal of sulphur from heavy oils as well as the removal of heavy metals.

Continuous research and successful applications affirm the fact that MEOR can be viewed as a potent technology $[8,22,23]$ despite the existing disagreement by some groups [24]. However, successful MEOR field applications reported are specific for each well and published information to support economic advantages is lacking. MEOR is, therefore, considered as one of the promising future research areas with great preference as identified by the Oil and Gas in the 21st Century Task Force [24]. This is probably because MEOR is an alternate technology that may help in recovering the 377 billion barrels of oil that are unrecoverable by conventional technologies [8].

\section{The Bygone Days of MEOR}

It was Beckman in 1926 [25] who suggested for the first time that microbes could be used to recover oil from porous media. 
Between 1926 and 1940, not many studies were held on this topic. In the 1940s, Zobell [26] started a series of systematic laboratory findings which marked the beginning of a new era of petroleum microbiology research with application in oil recovery. According to Zobell the main mechanisms behind oil release from porous media are processes such as bacterial metabolites that break up inorganic carbonates; bacterial gases which reduce the viscosity of oil, thereby increasing its flow; surface-active substances or wetting agents produced by some bacteria; and the high affinity of bacteria for solids to crowd off the oil films, processes by which bacterial products (gases, acids, solvents, surface-active agents, and cell biomass) releasing oil from the sand pack columns in wet labs were patented by Zobell. Later Updegraff et al. repeated [27, 28] Zobell's experiments and patented [29] the process which is based on the bacterial byproducts produced from cheap substrates like molasses to assist the oil recovery. The first field test was carried out in the Lisbon field, Union County, AR [30]. Kuznetsov et al. [31] concluded that anaerobic bacteria present in the oil deposits can utilize oil to form gaseous products $\left(\mathrm{CH}_{4}, \mathrm{H}_{2}, \mathrm{CO}_{2}, \mathrm{~N}_{2}\right)$. Kuznetsov's work demonstrated the technology of microbial flora activation of reservoirs, later advanced by Ivanov et al. [32]. Extensive research on MEOR was conducted in the 1960s and 1970s, in Czechoslovakia, Hungary, and Poland [33-35]. The field trials were based on the injection of mixed anaerobic or facultative anaerobic bacteria (Clostridium, Bacillus, Pseudomonas, Arthrobacterium, Micrococcus, Peptococcus, Mycobacterium, etc.) selected on their ability to generate gases, acids, solvents, polymers, surfactants, and cell biomass. At the same time, another technology named as selective plugging recovery has been recognized as an important additional mechanism for improving the oil recovery from water floods. This is achieved by producing polysaccharide slime in situ by an injected microbial system based on molasses. Microbes producing biopolymers of xanthan or scleroglucan types as viscosifying agents were isolated, which greatly enhanced oil recovery [36-38]. The investigations during 1970-2000 have demonstrated the basic nature and existence of indigenous microbiota in oil reservoirs, as well as reservoir characteristics essential to a successful MEOR application. It was also proved that the cyclic microbial recovery (single well stimulation), microbial flooding recovery, and selective plugging recovery are very effective. The technology based on activation of stratal microbiota was successfully developed in former Soviet Union $[32,39]$. It can be concluded that the petroleum crisis during 1970s led to substantial MEOR research and later became a scientifically identified EOR method, supported by research projects carried out all over the world in countries such as the USA, Canada, Australia, China, Russia, Romania, Poland, Hungary, Czech Republic, Great Britain, Germany, Norway, and Bulgaria. Many international meetings were periodically organized on the MEOR topic with the publication of proceedings carrying the advances in the knowledge and practice of MEOR techniques. It is important to recognize and acknowledge the role of the U.S. Department of Energy (DOE), which sponsored MEOR basic research and field trials, as well as periodically organizing international meetings. Several books on MEOR were also published [40-42]. Grula et al. [43] developed a microbial screening method to isolate an anaerobic Clostridium species that produced gases, acids, alcohols, and surfactants. But all those strains isolated showed intolerance to high salt concentrations $(>7 \%)$ which remained as a major problem. Success of in situ MEOR processes depends upon isolating microorganisms that can survive and produce the desired metabolic products in reservoirs containing hydrocarbons and saline water. Continuous investigations were done on different microbial species such as Clostridium species, Bacillus species, and Enterobacter for better adaptation to reservoir conditions. By the end of the 1990s, MEOR was recognized as a scientific and interdisciplinary technique for the increase of oil recovery.

In 1995, a survey of 322 MEOR projects in the USA showed that $81 \%$ of the projects successfully increased oil production, and neither of them had shown reduced oil production [7]. Today, MEOR technologies are well suited for application, when there is a need for oil crisis at a rate of 3 to $4 \%$ /year. Since 1980, the abolition of stripper wells has increased to $175 \%$ [9], and accordingly, within $15-25$ years, the USA could have access to less than $25 \%$ of its remaining oil resources. MEOR technologies were very slowly recognized by industry even though a long history of MEOR activity exists, due to the lack of published data especially in widely available journals, as well as too little cooperation between microbiologists, reservoirs engineers, geologists, economists, and owner operators.

\section{Laboratory and Field MEOR Projects}

Zobell [44] patented a process for the secondary oil recovery, using anaerobic, hydrocarbon-utilizing, and sulfate-reducing bacteria such as Desulfovibrio species in situ. He reported that the oil recovery mechanism was similar to Clostridium, where bacterial cells (and the hydrogenase enzyme system) produces the acids and ammonium hydroxide by using $\mathrm{CO}_{2}$, water and nitrates present in the reservoir, which helps to enhance the release of oil from reservoir rock when supplied with nutrients.

Various "agroindustrial carbohydrates based" substrates are proposed as a suitable "carbon source" for MEOR applications, like molasses [17, 45]. Updegraff and Wren [27] proposed that fermentative bacteria such as Desulfovibrio use nutrients such as molasses to produce large amounts of organic acids and carbon dioxide to enhance oil recovery in wet labs. The process was patented by them in spite of the major drawback of Desulfovibrio species producing hydrogen sulfide which is not suitable for MEOR processes. MEOR research team at Sultan Qaboos University, Oman, have reported isolation, identification, and bioproducts production by spore-forming Bacilli spp., and its potential role in enhancing oil recovery at laboratory scale [13, 17-21]. Bond [46] injected 5,000 gal of agar medium containing sand and Desulfovibrio hydrocarbonoclasticus, which is no longer a valid species into a sandstone reservoir at a depth of 3,000 ft. The well initially produced $15 \mathrm{bbl} /$ day. After the inoculum injection, the well was shut in for 3 months for the bacterial 
growth and action. The well, when it started the production again, produced $25 \mathrm{bbl} /$ day.

Hitzman [47] patented a process of injecting bacterial spores along with nutrients into a reservoir. The spores would germinate in the reservoir and enhance oil recovery from reservoir rock. A medium containing molasses and spores of Clostridium roseum was passed through the sand-packed column saturated with oil and showed about $30 \%$ increase in release of oil.

Patents by Hitzman $[36,47]$ used microorganisms that utilized injected polymers and the byproducts of $\mathrm{CO}_{2}$ floods, to produce products such as gases, acids, solvents, and surfactants for EOR. In polymer floods, the injected organisms feed on polymer that is adsorbed on the reservoir rock. In $\mathrm{CO}_{2}$ floods, the microbes feed on soluble compounds of carbon, nitrogen, and sulfur left behind by the $\mathrm{CO}_{2}$-crude oil slug. The process was demonstrated in sand-pack, but no core or field tests are reported.

Knapp et al. [48] reported the isolation of 22 microorganisms that produce biopolymers and emulsifiers. Among them, one strain could thrive at $10 \%$ salt concentrations, over a $\mathrm{pH}$ range of 4.6 to 9.0 , at temperatures up to $50^{\circ} \mathrm{C}$, in presence of crude oil. They demonstrated that glucose, ammonium sulfate, and potassium phosphate were easily transported through sandstone cores. Viable bacterial cells in aqueous solutions of $2 \% \mathrm{NaCl}$ and $0.01 \% \mathrm{CaCl}_{2}$ injected into these cores were not recovered in the effluent. The cores were inoculated with bacteria and nutrients such as glucose were added which resulted in a significant decrease in permeability. This could be because of the plugging of pores by the bacterial mass. The prominent bacteria indigenous to all of the cores treated were found as Pseudomonas sp., Bacillus sp., and Actinomycetes. A major problem in these experiments was the determination of the amount of plugging caused by injected bacteria and the amount by inhabitant ones. The problem existed even when cores were steam-sterilized and autoclaved. "Sterilization" of cores with chlorine dioxide helped to get rid of the problem, but the bacterial populations returned after $48 \mathrm{~h}$ incubation.

Johnson [49] studied 150 stripper wells in the USA that produced, on an average, $2 \mathrm{bbl} / \mathrm{day}$, with no well head pressure. The reservoir porosities were 10 to $30 \%$, depths 200 to $1,000 \mathrm{ft}$, with an average reservoir temperature of $38^{\circ} \mathrm{C}$. In his study, he inoculated a mixed culture of Bacillus and Clostridium spp. (1 to $10 \mathrm{gal}$ ) with crude molasses and mineral salts as nutrients. Approximately 10 to 14 days were needed for the optimal growth of cells in the treated area of the reservoir. The results varied, but an average of 20 to $30 \%$ additional oilin-place was recovered.

The preliminary field tests done by Petrogen, Inc., during $1977-88$ in 24 wells with varying depths from 300 to $4,600 \mathrm{ft}$., demonstrated a pressure increase of 10 to $200 \mathrm{psi}$ in $75 \%$ of the wells. Four wells doubled production for 6 months, and 12 increased production by $50 \%$ for 3 months. The average production increase was indicated as $42 \%$; however, the final results remain to be reported [50]. Jack et al. [51] considered that emulsification of viscous crude oil in situ is not a feasible method for EOR since transporting the bacteria through the reservoir rock would face some difficulties. Yarbrough and
Coty [30] reported a field test performed by them in 1954 in Arkansas, in which Clostridium acetobutylicum was injected along with a $2 \%$ solution of beet molasses in fresh water during a 6-month period. 70 days after starting the injection, freshwater breakthrough occurred at the production well. Fermentation products such as short-chain fatty acids, $\mathrm{CO}_{2}$, and traces of ethanol, 1-butanol, and acetone and sugars were found 80 to 90 days after the injection started. There was no increase in hydrogen content. Production of oil increased from $0.6 \mathrm{bbl} /$ day to $2.1 \mathrm{bbl} /$ day. Field test studies were not conducted.

The first MEOR project in the Rocky Mountains was started in 1983 [52]. An independent oil operator acquired three field service operations from Petroleum Bio-Resources Company. These were (a) a reservoir field conditioning system to avoid plugging; (b) use of a microorganism that produces gas and surfactant; and (c) use of a microorganism that produces a polysaccharide for mobility control. It was stated that production immediately doubled due to well stimulation and also increased oil recovery from 26 to $60 \mathrm{bbl} /$ day, probably due to mobilization of oil by microorganisms, and water flooding was also noticed in other fields [53]. Bryant and Douglas [54] demonstrated the oil recovery efficiency of several different bacterial strains in Berea sandstone cores. They reported that additional 32\% oil was recovered as compared to water flooding, and some spore-forming bacteria even showed $50-60 \%$ additional oil recovery. Berea sandstone core experiments showed that selected microbial strains could recover up to $72 \%$ of the heavy oil (API $14^{\circ}$ and $17^{\circ}$ ) left after water flooding.

7.1. Field Tests. Kuznetsov [55] reported that bacteria were present in certain oil-gas-bearing strata in the Saratov and Buguruslan areas of the USSR in such numbers that large quantities of $\mathrm{CO}_{2}$ were generated (depth was approximately $3,300 \mathrm{ft}$ ). Certainly methane was also formed. In the later works, Kuznetsov et al. [31] introduced a mixed culture of aerobic and anaerobic bacteria with acid-hydrolyzed substances from peat and soils and shut in the well for 6 months, and after that the well was opened for production [50]. The rate of oil production rose from 275 to $300 \mathrm{bbl} /$ day; however, 4 months later it had fallen to $270 \mathrm{bbl} /$ day. Field tests were done by Dostálek and Spurny [33] in Czechoslovakia where they injected sulfate-reducing (Desulfovibrio) and hydrocarbonutilizing (Pseudomonas) bacteria with nutrients (molasses). During six-month experiment period, the daily average oil production increased by nearly $7 \%$. No further work has been reported since 1958. Heningen et al. [56] reported on two field tests performed in the Netherlands, in which they used Betacoccus dextranicus in a sucrose-molasses medium of $10 \%$ total sugar content and obtained a $30 \%$ increase in cumulative oil recovery. A mixed culture of slime-forming bacteria in $50 \%$ molasses was used in the subsequent field trial. The oilto-water production ratio changed to $1: 20$ compared to $1: 50$ before the treatment.

In Hungary, to recover naphthenic crude, Jaranyi et al. [57] utilized a mixture of anaerobic thermophilic bacteria that fermented molasses. They also tried with raw sewage 
as an inoculum (100 L, along with 20 to $40,000 \mathrm{~kg}$ molasses) in their later trials (1969-70). The deepest reservoir was $8,200 \mathrm{ft}$, where the pressure was $228 \mathrm{~atm}$ and the temperature was $97^{\circ} \mathrm{C}$. In $70 \%$ of the reservoirs tested, the introduced microbial populations showed positive results on overall oil recovery.

Karaskiewicz [58] conducted 18 field trials in Poland between 1961 and 1969. Microbial cultures were obtained from soil and water samples which were collected from the nearby areas of the oil fields and from sugar factory waters. The mixed culture includes the genera Arthrobacter, Clostridium, Mycobacterium, Peptococcus, and Pseudomonas grown in $10 \mathrm{~L}$ bottles with formation water plus $4 \%$ molasses, incubated at $32^{\circ} \mathrm{C}$. The wells ranged in depth from 1,650 to $5,000 \mathrm{ft}$. The rate of additional oil recovery ranged from 20 to $200 \%$ of the original production rate. An additional supply of nutrients was proved to be a major factor for the increased oil recovery. Lazar [59] published an extensive review of MEOR work done in Romania during the last decade, in which he discussed three major areas in MEOR including (a) isolation of the bacterial population from the formation water of the reservoir; (b) adaptation of these microorganisms in wet lab for oil release; and (c) field testing of such adapted cultures. Seven wells were treated with microbial formulations, and he concluded that the bacterial population caused an increase of oil flow up to $200 \%$ for 1 to 5 years in 2 out of 7 reservoirs (the other five were unaffected), and much information about the ecology of the reservoir is needed before initiating any MEOR activity. A list of various reported successful MEOR applications at laboratory scale and field are listed in Table 1.

\section{Heavy Oil}

Heavy crude oil or extra heavy crude oil is a type of crude oil which does not flow easily. It is referred to as "heavy" because of its density or specific gravity, which is higher than that of light crude oil. Heavy crude oil has been defined as any liquid petroleum with API gravity less than $20^{\circ}$, which means its specific gravity is greater than 0.933 . This type of oil forms due to the exposure of crude oil to bacteria [60]. Production, transportation, and refining of heavy crude oil are much difficult compared to light crude oil. The largest reserves of heavy oil in the world are located in the north of the Orinoco River in Venezuela (Energy Information Administration, 2001) the same amount as the conventional oil reserves of Saudi Arabia, but 30 or more countries are known to have such heavy crude oil reserves. Heavy crude oil is closely related to oil sands; the main difference is that oil sands generally do not flow at all. Canada has large reserves of oil sands, located north and northeast of Edmonton, Alberta. Physical properties that distinguish heavy crudes from lighter ones include higher viscosity and specific gravity, as well as heavier molecular composition. Extra heavy oil from the Orinoco region has a viscosity of over 10,000 centipoise and $10^{\circ}$ API gravity. A diluent is added at regular distances in pipeline carrying heavy oil to increase the flow rate [61].
TABLE 1: Successful laboratory and field MEOR applications [7, 13, $17-21]$.

\begin{tabular}{ll}
\hline Country & Biological systems used \\
\hline & Pure or mixed cultures of Bacillus, \\
& Clostridium, Pseudomonas, and \\
& Gram-negative rods; mixed cultures of \\
& hydrocarbon degrading bacteria; mixed \\
USA & sultures of marine source bacteria; spore \\
& stratal microflora; slime-forming \\
& bacteria; ultramicrobacteria \\
& Pure cultures of C. tyrobutiricum; \\
& bacteria mixed cultures; indigenous \\
& microflora of water injection and water \\
& formation; activated sludge bacteria; \\
Russia & naturally occurring microbiota of \\
& industrial (food) wastes \\
& Mixed enriched bacterial cultures of \\
& Bacillus, Bacteroides, Eubacterium, \\
& Fusobacterium, Pseudomonas; \\
& slime-forming bacteria: Brevibacterium \\
viscogenes, Corynebacterium gumiform, \\
Xanthomonas campestris
\end{tabular}

Australia Ultramicrobacteria with surface active properties

Bulgaria Indigenous oil-oxidizing bacteria from water injection and water formation

Canada Pure culture of Leuconostoc mesenteroides Hydrocarbon oxidizing bacteria

Former Czechoslovakia (predominant Pseudomonas sp.); sulfate-reducing bacteria

England

Naturally occurring anaerobic strain, high generator of acids; special starved bacteria, good producers of exopolymers

Mixed cultures of thermophilic Bacillus

Former East Germany and Clostridium from indigenous brine microflora

Hungary

Mixed sewage-sludge bacteria cultures (predominant: Clostridium, Desulfovibrio, Pseudomonas)

Norway

Nitrate-reducing bacteria naturally occurring in North Sea water

Oman Autochthonous spore-forming bacteria from oil wells and oil contaminated soil

Poland Mixed bacteria cultures (Arthrobacter, Clostridium, Mycobacterium, Peptococcus, Pseudomonas)

Adapted mixed enrichment cultures Romania (predominant: Bacillus, Clostridium, Pseudomonas, and other Gram-negative rods)

Saudi Arabia Adequate bacterial inoculum according to requirements of each technology 
TABLE 1: Continued.

\begin{tabular}{ll}
\hline Country & Biological systems used \\
\hline The Netherlands & $\begin{array}{l}\text { Slime-forming bacteria } \\
\text { (Betacoccus dextranicus })\end{array}$ \\
Trinidad-Tobago & $\begin{array}{l}\text { Facultative anaerobic bacteria high } \\
\text { producers of gases }\end{array}$ \\
Venezuela & Adapted mixed enrichment cultures \\
\hline
\end{tabular}

8.1. Field Tests. Heavy crude oil plays a major role in the economics of petroleum development. The heavy oil resources in the world are more than twice those of conventional light crude oil. In October 2009, the USGS updated the Orinoco tar sands (Venezuela) recoverable value to 513 billion barrels $\left(8.16 \times 1010 \mathrm{~m}^{3}\right)$ (USGS. 11 January 2010), making this area the world's first recoverable oil deposit, ahead of Saudi Arabia and Canada [61]. The price of heavy crude oil slashes as compared to light oil due to increased refining costs and high sulphur content. The high viscosity and density also make production more difficult. On the other hand, large quantities of heavy crudes have been discovered in the Americas including Canada, Venezuela, and California. Another reason can be the relatively shallow depth of heavy oil fields (often less than 3000 feet) which contributes to lower production costs [62]. Special techniques are being developed for exploration and production of heavy oil.

8.2. Chemical Properties. Heavy oil contains asphaltenes and resins. It is "heavy" (dense and viscous) due to the high ratio of aromatics and naphthenes to paraffins (linear alkanes) and high amounts of NSOs (nitrogen, sulfur, oxygen, and heavy metals). The carbon chain in heavy oil has over 60 carbon atoms which results in a high boiling point and molecular weight. For example, the viscosity of Venezuela's Orinoco extra-heavy crude oil lies in the range of 1000-5000 cP (1$5 \mathrm{~Pa} \cdot \mathrm{s})$, while Canadian extra-heavy crude has a viscosity in the range of $5000-10,000 \mathrm{cP}(5-10 \mathrm{~Pa} \cdot \mathrm{s})$, about the same as molasses, and higher (up to $100,000 \mathrm{cP}$ or $100 \mathrm{~Pa} \cdot \mathrm{s}$ for the most viscous commercially exploitable deposits) [62]. A definition from the Chevron Phillips Chemical Company is as follows.

The "heaviness" of heavy oil is primarily the result of a relatively high proportion of a mixed bag of complex, high molecular weight, nonparaffinic compounds, and a low proportion of volatile, low molecular weight compounds. Heavy oils typically contain very little paraffin and may or may not contain high levels of asphaltenes.

\section{Development of Heavy Oil Reserves in Oman}

The first oil discovery in the Sultanate of Oman was accomplished in 1956, when City Services Company drilled Marmul-1 well. But the discovery was not considered as a commercial discovery because the oil found was heavy compared to oil discoveries in the Middle East at that time.
In 1962, Petroleum Development of Oman (PDO) exploration activities ended up in achieving commercial discovery of oil in Yibal field, followed by discoveries in Natih and Fahud fields in 1963 and 1964, respectively. These discoveries marked the birth of Oman as an oil producing country. The result of these successes in discovering and production of oil inspired the Government to sign two new agreements to explore oil and gas in 1973 and another two in 1975 with other international oil companies. By 2009, the number of active oil fields reached 135 . Over these days, Oman has been continuously applying efforts to improve the recovery of its oil reserves and has adopted EOR techniques on a large scale. These initiatives helped the Sultanate to increase their oil production capability to nearly 1 million barrels per day (bpd) from $714300 \mathrm{bpd}$ averaged in 2008 [63]. This has also changed the outlook for its oil industry which is now estimated to have at least 40 years of life ahead of it [64]. Al-Ghubar South's discovery in 2009 was the most auspicious discovery for Oman. According to the Ministry of Oil and Gas, this discovery could add as much as 1 billion barrels to reserves. Two other convincing discoveries, including that in Malaan West and Taliah in the Lekhwair cluster in northwest Oman, were made which will stretch the baseline production in the future [65].

9.1. First Trials. The first export of Omani oil took place on July 27,1967 . In the beginning, oil production increased steadily to 341000 barrels per day in 1975 and in 1984; the average daily production reached around 400000 barrels per day. Petroleum Development Oman (PDO) - the largest oilfield operator in Oman-started a series of EOR trials in 1986 due to low recovery of oil because of the complex geology of the reservoirs. The trials proved successful and Oman slowly started implementing EOR thereby boosting the production to a current level of nearly $900000 \mathrm{bpd}$. EOR projects result in 5-15 percent increment in reserves and $\mathrm{PDO}$ expects its EOR projects to contribute around 35 percent of its total production by 2020 . So Oman is considered as a country which is pushing the limits of EOR technology [66].

9.1.1. Miscible Gas Injection. Miscible gas injection involves pumping gas to oil wells. These gases that are being used for this purpose are often toxic which will dissolve in the oil and eventually lead to higher flow rates. This technique is currently at its operations in the Harweel oil field cluster [65].

9.1.2. Steam Injection. Qarn Alam is the world's first full field EOR project and also the largest of its kind in the world. Thermally assisted gas oil gravity drainage (TAGOGD), a sophisticated method, is employed due to the characteristics of the fractured carbonate reservoir, as the oil is highly viscous and a very low percentage of recovery is feasible by conventional oil extraction method.

9.1.3. Polymer Injection. Marmul field is located in south Oman. It is characterized by heavy viscous crude that is difficult to extract by traditional recovery methods. The reservoir has a viscosity of around $90 \mathrm{cP}$. The reservoir's sweep 
efficiency was modified by viscosifying the water with the addition of polyacrylamide polymers and then injected in the reservoir through polymer injection wells. The polymer flooding at Marmul field will increase a further recovery by $8000 \mathrm{bpd}$. By this technique, $10-15 \%$ increase in recovery levels from the Marmul reservoirs is predicted.

9.2. EOR Projects in Oman Oil Fields. Miscible gas injection has been applied in Harweel oil field which resulted in an additional production of 40,000 bbl/day. Thermal EOR methods are being deployed at Mukhaizna, Marmul, AmalEast, Amal-West, and Qarn Alam fields. Mukhaizna has already increased production to $50,000 \mathrm{bbl} / \mathrm{day}$, and the other fields, Amal-East and Amal-West, are expected to raise the production to $23,000 \mathrm{bbl} /$ day by 2018 . Furthermore, the steam injection at Qarn Alam is supposed to enhance the production by $40,000 \mathrm{bbl} /$ day by 2015 . This is achieved by a novel process in which steam drains oil to lower producer wells. At projects such as Marmul, with its heavy oil reserves, injecting polymer fluid has seen to be more effective.

Other EOR projects include Karim cluster, a cluster of 18 oil fields flowing to the Nimr production facility, in which PDO is aiming to boost up the production. In Harweel cluster, PDO estimates approximately 40 percentage increase in the next five years. Also with Rima clusters, using EOR techniques, much gain is expected (US Energy Information Administration, 2012).

\section{Role of Microbes in Biodegradation of Heavy Crude Oil}

Degradation of oil is one of the most important parts of the MEOR by which the oil's viscosity and freezing point are reduced which in turn will increase the oil's flow in situ. Heavy oils are rich in gum and asphaltene, having characteristics such as freezing point, low flow ability, difficult oil recovery, and high recovery cost [67].

Microbe can improve the physical characteristics of heavy oil in two ways: (1) by degrading heavy oil fractions, thereby decreasing the average molecular weight of heavy oil; and (2) the byproducts of microbial metabolism, such as biological surface active substance, acid, and gas, which can reduce the viscosity of oil considerably. Gum and asphaltene present in heavy oil have high molecular weight and polarity; meanwhile they are one of the main factors making the oil recovery difficult [68]. Usually, microbe hardly degrades them [69]. Zhang et al. [70] separated a variety of microbes from environments rich in petroleum and done a series of experiments using mixed microbial consortia, which can effectively degrade heavy oil, even gum and asphaltene; these microbes act by lowering the viscosity and freezing point of heavy oil and thereby improving the physical and chemical characters of heavy oils.

In some cases, using microbial consortia with different properties (ability to degrade heavy oil fractions and biosurfactant production) thereby applying different mechanisms might have a desired effect for enhanced oil recovery [71]. There are a lot of microbes having the ability to degrade hydrocarbons by using them as carbon sources [72]. Interesting results for the microbial $n$-alkane degradation have been reported during the past decades [73-76]. Extensive studies have been made on strains of Gordonia amicalis which have shown to be a potent degrader of large n-alkanes under aerobic and anaerobic conditions [77]; many Pseudomonas species have the ability to degrade lighter hydrocarbons with carbon chain length $\mathrm{C}_{12}-\mathrm{C}_{32}$, and heavier hydrocarbons with carbon chain length of $\mathrm{C}_{36}-\mathrm{C}_{40}[78,79]$; and a thermophilic Bacillus strain that degrades only long-chain $\left(\mathrm{C}_{15}-\right.$ $\mathrm{C}_{36}$ ) hydrocarbons but not short-chain $\left(\mathrm{C}_{8}-\mathrm{C}_{14}\right)$ n-alkanes [80] has also been reported. The ability of biosurfactantproducing indigenous Bacillus strains to degrade the higher fractions of crude oil and aid in the enhancement of its flow characteristics has also been studied for a petroleum reservoir in the Daqing Oilfield [81]. The MEOR team in the Sultan Qaboos University, Oman, found that a consortia of Bacillus strains form oil contaminated soil degraded heavy chain oil $\left(\mathrm{C}_{50}-\mathrm{C}_{70}\right)$ to $\left(\mathrm{C}_{11}-\mathrm{C}_{20}\right)$. Many microorganisms contain genes coding for the enzymes responsible for degrading petroleum hydrocarbons. Some microorganisms degrade alkanes (normal, branched, and cyclic paraffins), others aromatics, and others both paraffinic and aromatic hydrocarbons [82-84]. The most readily degraded alkanes are considered to be in in the range of $\mathrm{C}_{10}$ to $\mathrm{C}_{26}$, but lowmolecular-weight aromatics, such as benzene, toluene, and xylene, which are considered as the toxic compounds found in petroleum, are also readily biodegraded by many marine microorganisms. As the complexity of the structures (those with branches and/or condensed ring structures) increases, it will be more resistant for biodegradation, which means only fewer microorganisms can degrade those structures and the biodegradation rates would be much lower than the rates for the simpler hydrocarbon structures found in petroleum. The higher the number of methyl-branched components or condensed aromatic rings, the slower the rates of biodegradation and the greater the probability of accumulating partially oxidized intermediary metabolites.

Petroleum contains numerous compounds of varying structural complexities. The residual mixture formed after petroleum biodegradation may resist further biodegradation. Crude oils are never completely degraded and always result in some complex residue which appears as a black tar containing a high proportion of asphaltic compounds. The toxicity and bioavailability of the residual mixture are very low as long as it does not coat and suffocate an area, thus becoming an inert environmental contaminant with no toxic effects on environment [60].

About $10 \%$ of the total bacterial population in hydrocarbon-contaminated marine environments is hydrocarbon-degrading bacterial populations [82]. The major metabolic pathways for hydrocarbon biodegradation have been elucidated [85]. The initial steps in the biodegradation of hydrocarbons by bacteria are the oxidation of the oil by oxygenases. Alkanes are subsequently converted to carboxylic acids that are further biodegraded via $\beta$-oxidation (the central metabolic pathway for the utilization of fatty acids from lipids, which results in the formation of acetate, enters into the tricarboxylic acid cycle). Generally aromatic 
hydrocarbon rings are hydroxylated to form diols, which are then eventually cleaved to form catechols which are subsequently degraded to intermediates of the tricarboxylic acid cycle. Interestingly, the intermediates resulting from bacterial action are with differing stereochemistry usually cis-diols, which are biologically inactive. With bacteria being the dominant hydrocarbon degraders in the marine environment, the products of aromatic hydrocarbons biodegradation will detoxify them and do not produce potential carcinogens. The complete biodegradation (mineralization) of hydrocarbons produces environmentally safe end products such as carbon dioxide and water, as well as cell biomass (largely protein) which will eventually enter into the food web.

\section{Microbial Candidates Involved in Crude Oil Degradation}

11.1. Thermophilic Spore-Forming Bacteria Involved in Biodegradation of Heavy Crude Oil for MEOR. Many varieties of microbes are identified and isolated from different petroleum reservoirs which comprise several ecological niches, including sulfate reducers [86-88], sulfur reducers [86], methanogen [88], fermentative bacteria $[89,90]$, manganese and iron reducers [91], and dibenzothiophene-degrading bacteria [92]. Although many bacteria are isolated from many reservoirs, those which can be applied to MEOR are fewer.

Many researchers have been engaged in studying thermophiles. It is reported that 140 species of 70 genera of thermophiles have been discovered from high temperature environments with wide applications [93]. In the Shengli oil field of East China, where extreme physical conditions exist with temperature ranging $60-90^{\circ} \mathrm{C}$ and depth of $1000-$ $2000 \mathrm{~m}$, most of the reservoirs are under EOR. This harsh environment seems to be unsuitable for microbial growth. But some thermophiles have been isolated which helps in EOR [86].

There are many kinds of Bacillus, which are distributed widely, but those which have application on crude oil recovery are very few $[94,95]$. B. subtilis and B. licheniformis strains have been repeatedly isolated from many oil reservoirs as well as oil contaminated samples, thus confirming the adaptability of these species [17-19, 95-101]. The properties of B. subtilis have been reported in much literature [17-19, 96, 102-104], but the isolation and its action on crude oil have been scarcely reported [95].

It is recognized that the thermophiles possess enzymes which are more resistant to physical and chemical denaturation. Their faster growth rates also serve as another major advantage. Relative studies suggest that thermophilic hydrocarbon degraders of Bacillus, Thermus, Thermococcus, and Thermotoga species occurring in natural hightemperature or sulfur-rich environments are of special significance [105]. Wang et al. [106] isolated functional bacteria from high temperature petroleum reservoirs. Three thermophilic hydrocarbon-degrading bacteria, which belonged to Bacillus sp., Geobacillus sp., and Petrobacter sp., could tolerate $55^{\circ} \mathrm{C}$ in obligate anaerobic condition. These strains could utilize crude oil as carbon source with the degradation rate of $56.5 \%, 70.01 \%$, and $31.78 \%$, respectively, along with the viscosity reduction rate of $40 \%, 54.55 \%$, and $29.09 \%$, meanwhile the solidify points of crude oil were reduced by 3.7, 5.2, and $3.1^{\circ} \mathrm{C}$.

Hao et al. [107] isolated a hydrocarbon-degrading bacterium, strain SB-1, from oil-contaminated soil samples collected at the Shengli oil field in east China. Based on 16S rDNA sequence, the strain was identified as B. subtilis. The bacteria degraded $39.33 \%$ of crude oil, $57.01 \%$ of the saturated fractions, $25.63 \%$ of the resins, and $12.15 \%$ of the aromatic fractions within 12 days. In addition, more than $50 \%$ of the alkanes were removed by the strain; the highest degradation rate was shown as $81.03 \%$ for $\mathrm{C}_{36}-\mathrm{C}_{40}$, and the lowest degradation rate being $51.47 \%$ for $\mathrm{C}_{31}-\mathrm{C}_{35}$. The results of this study concluded that $B$. subtilis SB-1 is a potent strain in degrading oil pollutants in soil.

Sanchez et al. [108] isolated thermophilic bacteria enriched from the formation waters of a Venezuelan oil field. The reservoir, located at Maracaibo Lake, has a temperature of $60-80^{\circ} \mathrm{C}$ and a pressure of $1,200-1,500$ psi. The main fermentative byproducts were alcohols, short chain fatty acids, and gases when grown in media with industrial wastes as carbon source.

A strain of B. stearothermophilus (Geobacillus) was isolated from oil-contaminated Kuwaiti desert capable of growing on $\mathrm{C}_{15}-\mathrm{C}_{17}$ [109], and two strains of $G$. jurassicus were isolated from a high temperature petroleum reservoir capable of growing on $\mathrm{C}_{6}-\mathrm{C}_{16}$ [110]. B. thermoleovorans strain isolated from deep subterranean petroleum reservoirs was shown to degrade n-alkane up to $\mathrm{C}_{23}$ at $70^{\circ} \mathrm{C}$ [111]. Thermophilic, glucose-fermenting, strictly anaerobic, rodshaped bacterium, Thermotoga hypogea sp. strain SEBR 6459T ( $\mathrm{T}=$ type strain), was isolated from an African oilproducing well [112] and T. elfii strain SEBR 6459 by Ravot et. al. [113]. Al-Bahry et al. [18-21, 96] reported 33 genera and 58 species identified from Omani oil wells. All of the identified microbial genera were first reported in Oman, with Caminicella sporogenes for the first time reported from oil fields. Most of the identified microorganisms were found to be anaerobic, thermophilic, and halophilic and produced biogases, biosolvents, and biosurfactants as by-products, which may be potentially applicable in MEOR.

Various bioremediation and biodegradation agents are commercially available consisting of microbial cultures or microbial enzymes or both. The US Environmental Protection Agency National Contingency Plan released a product schedule report on August 2013 [114]. Also various laboratory screening reports are available for these commercial products [115].

\section{Conclusions}

Given the scarcity of the literature on thermophilic sporeforming bacteria involved in MEOR for crude oil biodegradation, there is a clear need for further laboratory research. 
While significant progress has been made, we still need to rigorously examine this mechanism of MEOR.

\section{Conflict of Interests}

The authors declare that there is no conflict of interests regarding the publication of this paper.

\section{References}

[1] K. Aleklett, M. Höök, K. Jakobsson, M. Lardelli, S. Snowden, and B. Söderbergh, "The peak of the oil age-analyzing the world oil production reference scenario in world energy outlook 2008," Energy Policy, vol. 38, no. 3, pp. 1398-1414, 2010.

[2] W. Graus, M. Roglieri, P. Jaworski, L. Alberio, and E. Worrell, "The promise of carbon capture and storage: evaluating the capture-readiness of new EU fossil fuel power plants," Climate Policy, vol. 11, no. 1, pp. 789-812, 2011.

[3] R. Cossé, Basics of Reservoir Engineering, Pure and Applied Geophysics, Éditions Technip, 1993.

[4] C. Hall, P. Tharakan, J. Hallock, C. Cleveland, and M. Jefferson, "Hydrocarbons and the evolution of human culture," Nature, vol. 426, no. 6964, pp. 318-322, 2003.

[5] R. S. Bryant, A. K. Stepp, K. M. Bertus, T. E. Burchfield, and M. Dennis, "Microbial-enhanced waterflooding field pilots," Developments in Petroleum Science, vol. 39, pp. 289-306, 1993.

[6] L. W. Lake, Enhanced Oil Recovery, Prentice Hall, Englewood Cliffs, NJ, USA, 1989.

[7] I. Lazar, I. G. Petrisor, and T. F. Yen, "Microbial enhanced oil recovery (MEOR)," Petroleum Science and Technology, vol. 25, no. 11, pp. 1353-1366, 2007.

[8] R. Sen, "Biotechnology in petroleum recovery: the microbial EOR," Progress in Energy and Combustion Science, vol. 34, no. 6, pp. 714-724, 2008.

[9] D. O. Hitzman, "Microbial enhanced oil recovery-the time is now," Developments in Petroleum Science, vol. 31, pp. 11-20, 1991.

[10] B. Bubela, "A comparison of strategies for enhanced oil recovery using in situ and ex situ produced biosurfactants," Surfactant Science Series, vol. 25, pp. 143-161, 1987.

[11] G. S. Derek, "Microbiological methods for the enhancement of oil recovery," Biotechnology and Genetic Engineering Reviews, vol. 1, no. 1, pp. 187-222, 1984.

[12] S. Rebeka, "Potential uses of microorganisms in petroleum recovery technology," in Proceedings of the Oklahoma Academy of Science, 1987.

[13] R. Al-Hattali, H. Al-Sulaimani, Y. Al-Wahaibi et al., "Microbial biomass for improving sweep efficiency in fractured carbonate reservoir using date molasses as renewable feed substrate," in Proceedings of the SPE Annual Technical Conference and Exhibition, San Antonio, Tex, USA, 2012.

[14] H. Suthar, K. Hingurao, A. Desai, and A. Nerurkar, "Evaluation of bioemulsifier mediated microbial enhanced oil recovery using sand pack column," Journal of Microbiological Methods, vol. 75, no. 2, pp. 225-230, 2008.

[15] I. M. Banat, A. Franzetti, I. Gandolfi et al., "Microbial biosurfactants production, applications and future potential," Applied Microbiology and Biotechnology, vol. 87, no. 2, pp. 427-444, 2010.

[16] A. K. Sarkar, J. C. Goursaud, M. M. Sharma, and G. Georgiou, "Critical evaluation of MEOR processes," In Situ, vol. 13, no. 4, pp. 207-238, 1989.
[17] S. N. Al-Bahry, Y. M. Al-Wahaibi, A. E. Elshafie et al., "Biosurfactant production by Bacillus subtilis B20 using date molasses and its possible application in enhanced oil recovery," International Biodeterioration and Biodegradation, vol. 81, pp. 141-146, 2013.

[18] H. Al-Sulaimani, Y. Al-Wahaibi, S. N. Al-Bahry et al., "Experimental investigation of biosurfactants produced by Bacillus species and their potential for MEOR in Omani oil field," in Proceedings of the SPE EOR Conference at Oil and Gas West Asia 2010 (OGWA '10), pp. 378-386, Muscat, Oman, April 2010.

[19] H. Al-Sulaimani, Y. Al-Wahaibi, S. Al-Bahry et al., "Optimization and partial characterization of biosurfactants produced by Bacillus species and their potential for ex-situ enhanced oil recovery," SPE Journal, vol. 16, no. 3, pp. 672-682, 2011.

[20] H. Al-Sulaimani, Y. Al-Wahaibi, S. N. Al-Bahry et al., "Residualoil recovery through injection of biosurfactant, chemical surfactant, and mixtures of both under reservoir temperatures: induced-wettability and interfacial-tension effects," SPE Reservoir Evaluation and Engineering, vol. 15, no. 2, pp. 210-217, 2012.

[21] Y. Al-Wahaibi, H. Al-Hadrami, S. Al-Bahry, A. Elshafie, A. Al-Bemani, and S. Joshi, "Residual oil recovery via injection of biosurfactant and chemical surfactant following hot water injection in Middle East heavy oil field," in Proceeding of the SPE Heavy Oil Conference, Alberta, Canada, June 2013.

[22] K. Fujiwara, Y. Sugai, N. Yazawa, K. Ohno, C. X. Hong, and H. Enomoto, "Biotechnological approach for development of microbial enhanced oil recovery technique," Studies in Surface Science and Catalysis, vol. 151, pp. 405-445, 2004.

[23] H. Al-Sulaimani, S. Joshi, Y. Al-Wahaibi, S. N. Al-Bahry, A. Elshafie, and A. Al-Bemani, "Microbial biotechnology for enhancing oil recovery: current developments and future prospects," Biotechnology, Bioinformatics and Bioengineering Journal, vol. 1, no. 2, pp. 147-158, 2011.

[24] A. R. Awan, R. Teigland, and J. Kleppe, "A survey of North Sea enhanced-oil-recovery projects initiated during the years 1975 to 2005," SPE Reservoir Evaluation and Engineering, vol. 11, no. 3, pp. 497-512, 2008.

[25] J. W. Beckman, “The action of bacteria on mineral oil," Industrial and Engineering Chemistry, News Edition, vol. 4, pp. 23-26, 1926.

[26] C. E. Zobell, "Bacterial release of oil from oil-bearing materials," World Oil, vol. 126, pp. 36-47, 1947.

[27] D. M. Updegraff and G. B. Wren, "The release of oil from petroleum-bearing materials by sulfate-reducing bacteria," Applied Microbiology, vol. 2, no. 6, pp. 309-322, 1954.

[28] J. B. Davis and D. M. Updegraff, "Microbiology in the petroleum industry," Bacteriological Reviews, vol. 18, no. 4, pp. 215-238, 1954.

[29] D. M. Updegraff, "Recovery of petroleum oil," US Patent No. 2.807.570, 1957.

[30] H. F. Yarbrough and V. F. Coty, "Microbial enhanced oil recovery from the upper crustaceous nacatoch formation," in Proceedings of the International Conference on Microbial Enhancement of Oil Recovery, 1983.

[31] S. I. Kuznetsov, M. V. Ivanov, and N. N. Lyalikowa, Introduction to Geological Microbiology, McGraw-Hill, New York, NY, USA, 1963.

[32] M. V. Ivanov, S. S. Belyaev, M. A. Zyakun, A. V. Bondar, and S. K. Laurinavichus, "Microbiological formation of methane in the oil field development," Moscova, vol. 11, 1983.

[33] M. Dostálek and M. Spurny, "Bacterial release of oil. A preliminary trial in an oil deposit," Folia Biologica, vol. 4, pp. 166-172, 1958. 
[34] M. Dienes and I. Yaranyi, "Increase of oil recovery by introducing anaerobic bacteria into the formation Demjen field," Hungary Koolaj as Fodgas, vol. 106, no. 7, pp. 205-208, 1973.

[35] I. Karaskiewicz, "The application of microbiological method for secondary oil recovery from the Carpathian crude oil reservoir," Widawnistwo "SLASK”, pp. 1-67, 1974.

[36] D. O. Hitzman, "Review of microbial enhanced oil recovery field tests," in Proceedings of the Applications of Microorganisms to Petroleum Technology, U.S. Department of Energy, 1988.

[37] I. Lazar, "MEOR field trials carried out over the world during the past 35 years," in Microbial Enhancement of Oil RecoveryRecent Advances, E. C. Donaldson, Ed., 1991.

[38] I. Lazar, "International MEOR applications for marginal wells," Pakistan Journal of Hydrocarbon Research, vol. 10, pp. 11-30, 1998.

[39] M. V. Ivanov, S. S. Belyaev, I. A. Borzenkov, I. F. Glumov, and P. B. Ibatulin, "Additional oil production during field trials in Russia," in Microbial Enhancement of Oil Recovery-Recent Advances, E. Premuzic and A. Woodhead, Eds., 1993.

[40] J. E. Zajic, D. G. Cooper, T. R. Jack, and N. Kosaric, Microbial Enhanced Oil Recovery, Penn Well Books, Tulsa, Okla, USA, 1983.

[41] T. F. Yen, State of the Art Review on Microbial Enhanced Oil Recovery, NSF OIR-8405134, Los Angeles, Calif, USA, 1986.

[42] E. C. Donaldson, G. V. Chilingarian, and T. F. Yen, Microbial Enhanced Oil Recovery, Elsevier, New York, NY, USA, 1989.

[43] E. A. Grula, H. H. Russell, D. Bryant, M. Kanaga, and M. Hart, "Isolation and screening of Clostridia for possible use in microbially enhanced oil recovery," in Proceedings of the Microbial Enhanced Oil Recovery, Afton, Okla, USA, 1982.

[44] C. E. Zobell, "Bacteriological process for treatment of fluidbearing earth formations," US Patent No. 2, 413, 278, 1946.

[45] S. Joshi, C. Bharucha, S. Jha, S. Yadav, A. Nerurkar, and A. J. Desai, "Biosurfactant production using molasses and whey under thermophilic conditions," Bioresource Technology, vol. 99, no. 1, pp. 195-199, 2008.

[46] D. C. Bond, Bacteriological Method of Oil Recovery, Pure Oil Company, Rock Hill, SC, USA, 1961.

[47] D. O. Hitzman, "Microbiological secondary recovery of oil," U.S. Patent 3, 032, 472, 1962.

[48] R. M. Knapp, M. J. McInerney, D. E. Menzie, and G. E. Jenneman, "The use of microorganisms in enhanced oil recovery," in First Annual Report to the Department of Energy, 1983.

[49] A. C. Johnson, "Microbial oil release technique for enhanced oil recovery," in Proceedings of the Conference on Microbiological Processes Useful in Enhanced Oil Recovery, San Diego, Calif, USA, 1979.

[50] D. O. Hitzman, "Petroleum microbiology and the history of its role in enhanced oil recovery," in Proceedings of the International Conference on Microbial Enhancement of Oil Recovery, U. S. Department of Energy, Bartlesville, Okla, USA, 1982.

[51] T. R. Jack, B. G. Thompson, and E. D. Blasio, "The potential for use of microbes in the production of heavy oil," in Proceedings of the International Conference on Microbial Enhanced Oil Recovery, Afton, Okla, USA, 1982.

[52] R. Rountree, "Rocky mountain oil history," Western Oil Reporter, vol. 4, p. 77, 1984.

[53] J. E. Zajic, Proceedings of the 1st International MEOR Workshop, U.S. Department of Energy Report No. DOE/BC/10852-1, 1986.
[54] R. S. Bryant and J. Douglas, "Evaluation of Microbial Systems in Porous Media for EOR,” SPE Reservoir Engineering, vol. 3, no. 2, pp. 489-495, 1988.

[55] S. I. Kuznetsov, "Possibilities of production of methane in oil fields of Saratov and Buguruslan," Mikrobiologiia, vol. 19, no. 3, pp. 193-202, 1950.

[56] J. V. Heningen, A. J. DeHann, and J. D. Jansen, "Process for the recovery of petroleum from rocks," Netherlands Patent 80, 580, 1958.

[57] I. Jaranyi, L. Kiss, C. Salanczy, and J. Szolnoki, "Alteration of some characteristics of oil-wells through the effects of microbial treatment," in Proceedings of the 3rd International Science Conference on Geochemistry, 1963.

[58] J. Karaskiewicz, "Studies on increasing petroleum oil recovery from Carpathian deposits using bacteria," Nafta (Petroleum), vol. 21, pp. 144-149, 1975.

[59] I. Lazar, "Microbially enhanced oil recovery in Romania," in Proceedings of the International Conference on Microbial Enhanced Oil Recovery, Afton, Okla, USA, 1982.

[60] M. B. Dusseault, "Comparing Venezuelan and Canadian heavy oil and tar sands," in Proceedings of the Petroleum Society's Canadian International Petroleum Conference, Calgary, Canada.

[61] H. A. Rodriguez, P. Vaca, O. Gonzalez, and M. C. de Mirabal, "Integrated study of a heavy oil reservoir in the Orinoco Belt: a field case simulation," in Proceedings of the SPE Reservoir Simulation Symposium, pp. 309-310, June 1997.

[62] S. Chopra and L. Lines, "Introduction to this special section: heavy oil," The Leading Edge, vol. 27, no. 9, pp. 1104-1106, 2008.

[63] http://www.engineerlive.com/content/23933.

[64] http://www.mog.gov.om/english/AboutUs/TheHistoryofOilGas/tabid/117/Default.aspx.

[65] http://www.eia.gov/countries/cab.cfm?fips=MU.

[66] http://www.reportlinker.com/p0155667/oman-oil-and-GasReport-Q4.html.

[67] G. L. Lei, "Research and application of microbial enhanced oil recovery," Acta Petrolei Sinica, vol. 22, no. 2, pp. 56-61, 2001.

[68] Y. S. Peng, H. S. Ji, and C. X. Liang, Field Research of Microbial Enhanced Oil Recovery, Petroleum Industry Press, Beijing, China, 1997.

[69] T. S. Zhang, G. Z. Lan, L. Deng, and X. G. Deng, "Experiments on heavy oil degradation and enhancing oil recovery by microbial treatments," Acta Petrolei Sinica, vol. 22, no. 1, pp. 54-57, 2001.

[70] T. S. Zhang, X. Chen, G. Z. Lan, and Z. Jiang, "Microbial degradation influences on heavy oil characters and MEOR test," in Proceedings of the 18th World Petroleum Congress, Johannesburg, South Africa, September 2005.

[71] L. Jinfeng, M. Lijun, M. Bozhong, L. Rulin, N. Fangtian, and Z. Jiaxi, "The field pilot of microbial enhanced oil recovery in a high temperature petroleum reservoir," Journal of Petroleum Science and Engineering, vol. 48, no. 3-4, pp. 265-271, 2005.

[72] A. Wentzel, T. E. Ellingsen, H. K. Kotlar, S. B. Zotchev, and M. Throne-Holst, "Bacterial metabolism of long-chain n-alkanes," Applied Microbiology and Biotechnology, vol. 76, no. 6, pp. 12091221, 2007.

[73] V. G. Grishchenkov, R. T. Townsend, T. J. McDonald, R. L. Autenrieth, J. S. Bonner, and A. M. Boronin, "Degradation of petroleum hydrocarbons by facultative anaerobic bacteria under aerobic and anaerobic conditions," Process Biochemistry, vol. 35, no. 9, pp. 889-896, 2000. 
[74] J. S. Sabirova, M. Ferrer, D. Regenhardt, K. N. Timmis, and P. N. Golyshin, "Proteomic insights into metabolic adaptations in Alcanivorax borkumensis induced by alkane utilization," Journal of Bacteriology, vol. 188, no. 11, pp. 3763-3773, 2006.

[75] A. Etoumi, I. El Musrati, B. El Gammoudi, and M. El Behlil, "The reduction of wax precipitation in waxy crude oils by Pseudomonas species," Journal of Industrial Microbiology and Biotechnology, vol. 35, no. 11, pp. 1241-1245, 2008.

[76] M. Binazadeh, I. A. Karimi, and Z. Li, "Fast biodegradation of long chain $\mathrm{n}$-alkanes and crude oil at high concentrations with Rhodococcus sp. Moj-3449," Enzyme and Microbial Technology, vol. 45, no. 3, pp. 195-202, 2009.

[77] D. H. Hao, J. Q. Lin, X. Song, J. Lin, Y. J. Su, and Y. B. Qu, "Isolation, identification, and performance studies of a novel paraffin-degrading bacterium of Gordonia amicalis LH3," Biotechnology and Bioprocess Engineering, vol. 13, no. 1, pp. 61-68, 2008.

[78] I. M. Banat, "Biosurfactants production and possible uses in microbial enhanced oil recovery and oil pollution remediation: a review," Bioresource Technology, vol. 51, no. 1, pp. 1-12, 1995.

[79] M. Hasanuzzaman, A. Ueno, H. Ito et al., "Degradation of longchain n-alkanes (C36 and C40) by Pseudomonas aeruginosa strain WatG," International Biodeterioration and Biodegradation, vol. 59, no. 1, pp. 40-43, 2007.

[80] L. Wang, Y. Tang, S. Wang et al., "Isolation and characterization of a novel thermophilic Bacillus strain degrading long-chain nalkanes," Extremophiles, vol. 10, no. 4, pp. 347-356, 2006.

[81] Y. H. She, F. Zhang, J. J. Xia et al., "Investigation of biosurfactantproducing indigenous microorganisms that enhance residue oil recovery in an oil reservoir after polymer flooding," Applied Biochemistry and Biotechnology, vol. 163, no. 2, pp. 223-234, 2011.

[82] R. M. Atlas, "Microbial degradation of petroleum hydrocarbons: an environmental perspective," Microbiological Reviews, vol. 45 , no. 1 , pp. $180-209,1981$.

[83] J. G. Leahy and R. R. Colwell, "Microbial degradation of hydrocarbons in the environment," Microbiological Reviews, vol. 54, no. 3, pp. 305-315, 1990.

[84] R. M. Atlas and R. Bartha, "Hydrocarbon biodegradation and oil spill bioremediation," Advances in Microbial Ecology, vol. 12, pp. 287-338, 1992.

[85] R. M. Atlas, Petroleum Microbiology, Macmillan, New York, NY, USA, 1984.

[86] K. O. Stetter, R. Huber, E. Blöchl et al., "Hyperthermophilic archaea are thriving in deep North Sea and Alaskan oil reservoirs," Nature, vol. 365, no. 6448, pp. 743-745, 1993.

[87] C. Tardy-Jacquenod, P. Caumette, R. Matheron, C. Lanau, O. Arnauld, and M. Magot, "Characterization of sulfate-reducing bacteria isolated from oil-field waters," Canadian Journal of Microbiology, vol. 42, no. 3, pp. 259-266, 1996.

[88] T. K. Ng, P. J. Weimer, and L. J. Gawel, "Possible nonanthropogenic origin of two methanogenic isolates from oil producing wells in the San Miguelito field, Ventura County, California," Geomicrobiology Journal, vol. 7, no. 3, pp. 185-192, 1989.

[89] M. E. Davey, W. A. Wood, R. Key, K. Nakamura, and D. A. Stahl, "Isolation of three species of Geotoga and Petrotoga: two new genera, representing a new lineage in the bacterial line of descent distantly related to the 'Thermotogales"' Systematic and Applied Microbiology, vol. 16, no. 2, pp. 191-200, 1993.

[90] G. S. Grassia, K. M. McLean, P. Glénat, J. Bauld, and A. J. Sheehy, "A systematic survey for thermophilic fermentative bacteria and archaea in high temperature petroleum reservoirs," FEMS Microbiology Ecology, vol. 21, no. 1, pp. 47-58, 1996.

[91] A. C. Greene, B. K. C. Patel, and A. J. Sheehy, "Deferribacter thermophilus gen. nov., sp. nov., a novel thermophilic manganeseand iron-reducing bacterium isolated from a petroleum reservoir," International Journal of Systematic Bacteriology, vol. 47, no. 2, pp. 505-509, 1997.

[92] A. Bahrami, S. A. Shojaosadati, and G. Mohebali, "Biodegradation of dibenzothiophene by thermophilic bacteria," Biotechnology Letters, vol. 23, no. 11, pp. 899-901, 2001.

[93] Z. He, Q. Peng, and J. Chen, Biology of Thermophiles, Scientific Press, Beijing, China, 2000.

[94] J. Li, B. Lian, J. Hao, J. Zhao, and L. Zhu, "Non-parallelism between the effect of microbial flocculants on sewerage disposal and the flocculation rate," Chinese Journal of Geochemistry, vol. 25, no. 2, pp. 139-142, 2006.

[95] G. E. Jenneman, M. J. McInerney, R. M. Knapp et al., "A halotolerant, biosurfactant producing Bacillus species potentially useful for enhanced oil recovery," Developments in Industrial Microbiology, vol. 24, pp. 485-492, 1983.

[96] S. N. Al-Bahry, A. Elshafie, Y. Al-Wahaibi et al., "Microbial consortia in Oman oil fields: a possible use in enhanced oil recovery," Journal of Microbiologyand Biotechnology, vol. 23, no. 1, pp. 106-117, 2013.

[97] M. M. Yakimov, K. N. Timmis, V. Wray, and H. L. Fredrickson, "Characterization of a new lipopeptide surfactant produced by thermotolerant and halotolerant subsurface Bacillus licheniformis BAS50," Applied and Environmental Microbiology, vol. 61, no. 5, pp. 1706-1713, 1995.

[98] S. M. M. Dastgheib, M. A. Amoozegar, E. Elahi, S. Asad, and I. M. Banat, "Bioemulsifier production by a halothermophilic Bacillus strain with potential applications in microbially enhanced oil recovery," Biotechnology Letters, vol. 30, no. 2, pp. 263-270, 2008.

[99] H. Ghojavand, F. Vahabzadeh, M. Mehranian et al., "Isolation of thermotolerant, halotolerant, facultative biosurfactantproducing bacteria," Applied Microbiology and Biotechnology, vol. 80, no. 6, pp. 1073-1085, 2008.

[100] N. Youssef, M. S. Elshahed, and M. J. McInerney, "Microbial processes in oil fields. Culprits, problems, and opportunities," Advances in Applied Microbiology, vol. 66, pp. 141-251, 2009.

[101] D. R. Simpson, N. R. Natraj, M. J. McInerney, and K. E. Duncan, "Biosurfactant-producing Bacillus are present in produced brines from Oklahoma oil reservoirs with a wide range of salinities," Applied Microbiology and Biotechnology, vol. 91, no. 4, pp. 1083-1093, 2011.

[102] D. G. Cooper, C. R. Macdonald, S. J. B. Duff, and N. Kosaric, "Enhanced production of surfactin from Bacillus subtilis by continuous product removal and metal cation additions," Applied and Environmental Microbiology, vol. 42, no. 3, pp. 408412, 1981.

[103] C. N. Mulligan, T. Y. K. Chow, and B. F. Gibbs, "Enhanced biosurfactant production by a mutant Bacillus subtilis strain," Applied Microbiology and Biotechnology, vol. 31, no. 5-6, pp. 486-489, 1989.

[104] G. Zheng and M. F. Slavik, "Isolation, partial purification and characterization of a bacteriocin produced by a newly isolated Bacillus subtilis strain," Letters in Applied Microbiology, vol. 28, no. 5, pp. 363-367, 1999. 
[105] H. Feitkenhauer, R. Müller, and H. Märkl, "Degradation of polycyclic aromatic hydrocarbons and long chain alkanes at 60$70^{\circ} \mathrm{C}$ by Thermus and Bacillus spp.", Biodegradation, vol. 14, no. 6, pp. 367-372, 2003.

[106] J. Wang, T. Ma, J. Liu et al., "Isolation of functional bacteria guided by PCR-DGGE technology from high temperature petroleum reservoirs," Huan Jing Ke Xue, vol. 29, no. 2, pp. 462468, 2008.

[107] R. Hao, M. Lv, and A. Lu, "Biodegradation of crude oil in soil by Bacillus subtilis SB-1," Current Topics in Biotechnology, vol. 6, pp. 49-55, 2011.

[108] G. Sanchez, A. Marin, L. Vierma, and T. P. Eugene, Isolation of Thermophilic Bacteria from a Venezuelan Oil Field, Developments in Petroleum Science, Elsevier, New York, NY, USA, 1993.

[109] N. A. Sorkhoh, A. S. Ibrahim, M. A. Ghannoum, and S. S. Radwan, "High-temperature hydrocarbon degradation by Bacillus stearothermophilus from oil-polluted Kuwaiti desert," Applied Microbiology and Biotechnology, vol. 39, no. 1, pp. 123-126, 1993.

[110] T. N. Nazina, D. S. Sokolova, A. A. Grigoryan et al., "Geobacillus jurassicus sp. nov., a new thermophilic bacterium isolated from a high-temperature petroleum reservoir, and the validation of the Geobacillus species," Systematic and Applied Microbiology, vol. 28, no. 1, pp. 43-53, 2005.

[111] T. Kato, M. Haruki, T. Imanaka, M. Morikawa, and S. Kanaya, "Isolation and characterization of psychrotrophic bacteria from oil-reservoir water and oil sands," Applied Microbiology and Biotechnology, vol. 55, no. 6, pp. 794-800, 2001.

[112] M. L. Fardeau, B. Ollivier, B. K. C. Patel et al., "Thermotoga hypogea sp. nov., a Xylanolytic, thermophilic bacterium from an oil-producing well,' International Journal of Systematic Bacteriology, vol. 47, no. 4, pp. 1013-1019, 1997.

[113] G. Ravot, M. Magot, M. L. Fardeau et al., "Thermotoga elfii sp. nov., a novel thermophilic bacterium from an African oilproducing well," International Journal of Systematic Bacteriology, vol. 45, no. 2, pp. 308-314, 1995.

[114] U.S. Environmental Protection Agency, National Contingency Plan, Product Schedule, 2013.

[115] R. J. Portier and L. M. Basirico, Laboratory Screening of Commercial Bioremediation Agents for the Deepwater Horizon Spill Response, Department of Environmental Sciences, Louisiana State University, Baton Rouge, La, USA, 2011. 


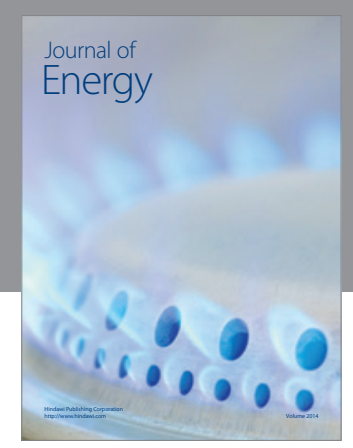

Journal of

Industrial Engineering
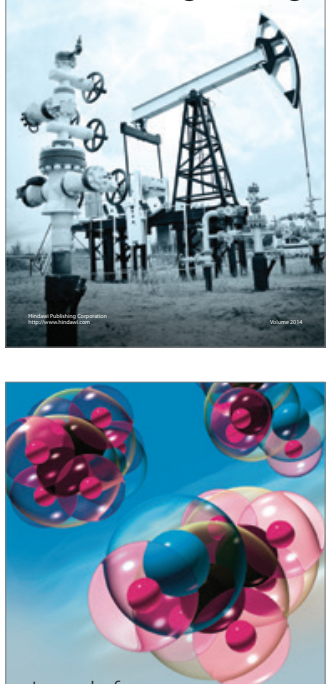

Fuels
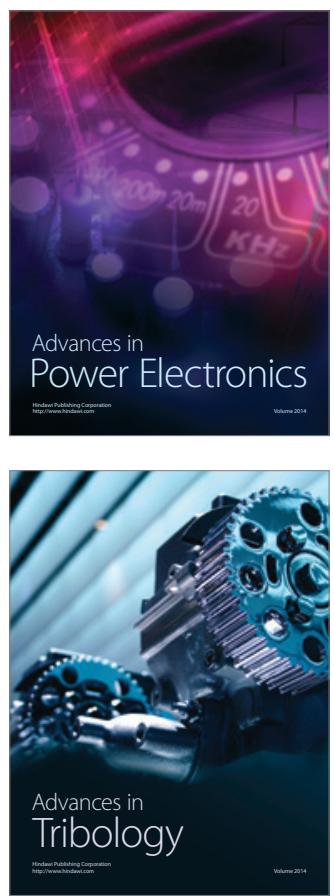

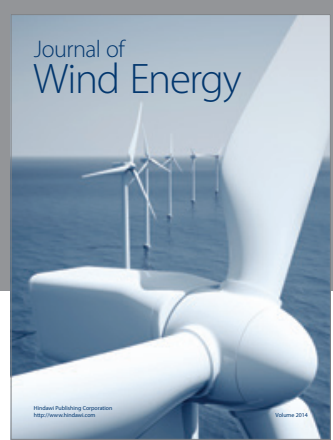

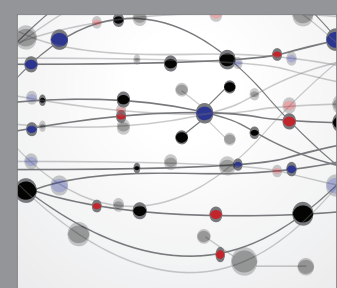

The Scientific World Journal

Submit your manuscripts at http://www.hindawi.com

Journal of

Structures
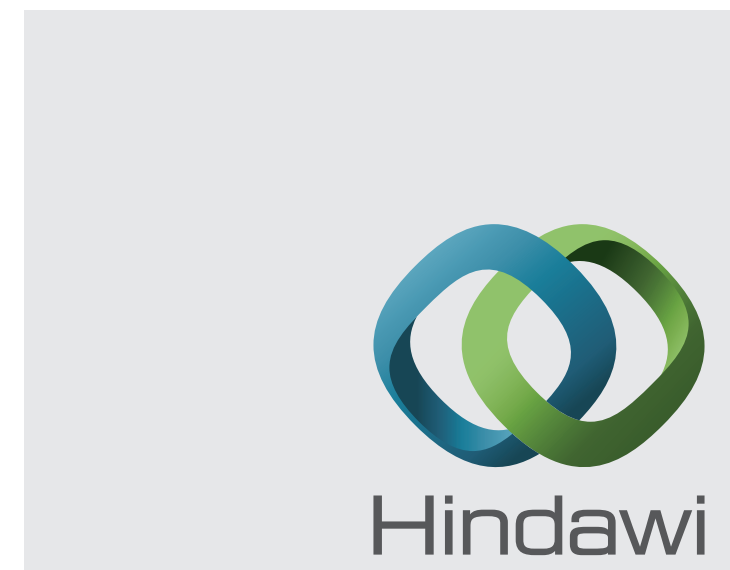

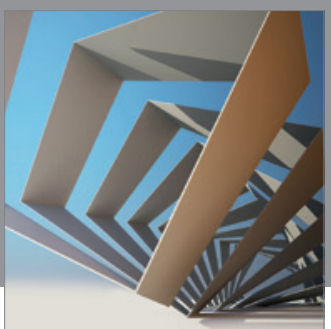

Rotating

Machinery
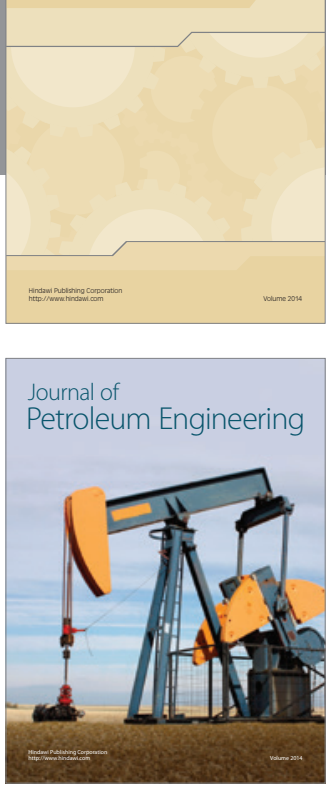

Journal of

Solar Energy
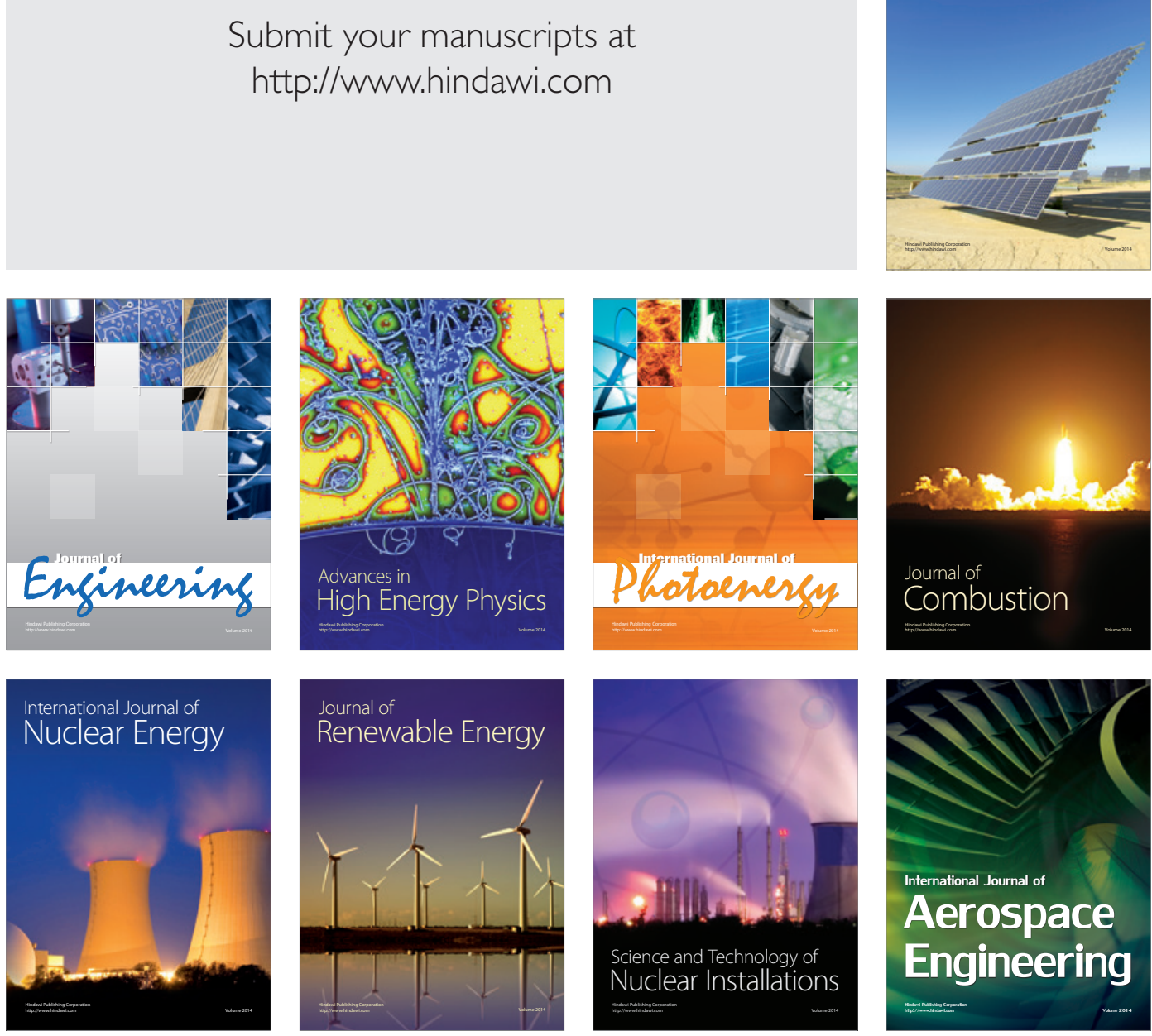